\title{
GROUP TAXATION, ASYMMETRIC TAXATION AND CROSS-BORDER INVESTMENT INCENTIVES IN AUSTRIA
}

RAINER NIEMANN

CORINNA TREISCH

\author{
CESIFO WORKING PAPER NO. 1506 \\ CATEgory 1: Public Finance \\ JULY 2005
}

An electronic version of the paper may be downloaded

- from the SSRN website: WwW.SSRN.com

- from the CESifo website: www.CESifo.de 


\title{
GROUP TAXATION, ASYMMETRIC TAXATION AND CROSS-BORDER INVESTMENT INCENTIVES IN AUSTRIA
}

\begin{abstract}
In 2005, Austria modified its group taxation regime and now provides an option for crossborder loss-offset. We analyse the combined impact of Austria's new group taxation and lossoffset limitations on cross-border investment decisions of domestic corporations. Monte Carlo simulations in an inter-temporal setting reveal that the impact on foreign real investment induced by the new group taxation is ambiguous. Whereas marginal investment projects with decreasing cash flows tend to benefit from group taxation, innovative projects with initial losses and increasing cash flows may be discriminated against. Investors should consider domestic income and repatriation policy simultaneously before opting for group taxation.
\end{abstract}

JEL Code: H25, G31.

Keywords: group taxation, investment decisions, Monte Carlo simulations, international taxation, loss-offset rules.

\author{
Rainer Niemann \\ University of Graz \\ Institute for Taxation and Accounting \\ Universitätsstr. 15 / FE \\ $8010 \mathrm{Graz}$ \\ Austria \\ niemann@uni-graz.at
}

\author{
Corinna Treisch \\ University of Duisburg-Essen/Campus Essen \\ Department of Economics and Business \\ Administration \\ Universitätsstr. 12 \\ 45117 Essen \\ Germany \\ ctreisch@uos.de
}




\section{Group Taxation, Asymmetric Taxation and Cross-Border Investment Incentives in Austria}

\section{Introduction}

In most countries, companies limited by shares and limited liability companies are subject to corporate income tax. Whereas corporate groups have to deliver consolidated financial statements for financial accounting purposes, they are not allowed to file consolidated tax statements. Instead, the parent company and its subsidiaries are taxed separately. Separate taxation ignores the fact that a corporate group constitutes an economic unit. As a consequence, many countries relaxed separate taxation for corporate groups and introduced group taxation regimes ${ }^{1}$. Group taxation regimes create tax integration by assigning all profits and losses within the corporate group to the parent company. Thus, group taxation provides an intra-group lossoffset.

In 2005, Austrian group taxation was modified substantially. Until 2004, group taxation could only be established between domestic corporations, while foreign subsidiaries were excluded from Austrian tax groups. Now, foreign subsidiaries can be integrated as well. By allowing for cross-border loss-offset, the tax legislator intended to improve Austria's attractiveness as a location for holding companies ${ }^{2}$. This policy was mainly triggered by tax competition from the new Eastern European EU member states. Moreover, the tax reform anticipates EU antidiscrimination rules. The European Court of Justice is expected to declare group taxation regimes which exclude foreign subsidiaries unlawful ${ }^{3}$. As a consequence, all member states would have to adapt their group taxation regimes. We therefore analyse from an economic perspective whether the Austrian tax reform can serve as a model for future European group taxation.

The Austrian tax literature widely appreciated the new group taxation ${ }^{4}$. However, its investment incentives are still unknown. In particular, the interaction of group taxation and asymmetric taxation of profits and losses remains to be analysed. The investment effects of group taxation are characterised by their relative impact on the different investment alternatives. We look at a

1 Cf. Russo (2005), p. 7.

2 Cf. reasons given for the draft law, Begründung des Gesetzentwurfs, Erläuterungen, Allg. Teil, B, http://www.bmf.gv.at/steuern/Neue Gesetze/Steuerreform/Erlaeuterungen.pdf (Download of 08.11.2004).

3 European Court of Justice, reference dated 16.07.2003, Case C-446/03 (Marks \& Spencer plc), order of the High Court of Justice of England and Wales for a preliminary ruling, OJ C-304/18 of 13.12.2003.

4 See, e.g., Gassner/Haidenthaler (2004) and the articles in Mühlehner/Zöchling (2004). 
two-stage corporate group. The parent company is located in Austria, while the subsidiary is based in another EU member state. In our investment model, the alternatives are real versus financial investment, both of which can be carried out either domestically by the parent company or in the foreign country by the subsidiary. If foreign real or financial investment is chosen, the investor decides whether or not to opt for group taxation.

This paper addresses the following questions:

- Does Austrian group taxation favour either domestic or foreign activities?

- Does Austrian group taxation favour either real or financial investment?

Our results will indicate whether group taxation actually improves Austria's attractiveness for setting up holding companies or whether unintended investment incentives prevail. The issue is relevant from an individual as well as a fiscal perspective. On the one hand, investors are given support for their individual investment decisions. On the other hand, tax authorities gain an insight into the effects of group taxation regimes, which can be used for improved predictions of tax revenue and better control of fiscal policy. As investment decisions are essentially multiperiod decisions, we will use an individual dynamic investment model to evaluate Austrian group taxation. In order to analyse the combined effects of group taxation and loss-offset restrictions under uncertainty, we perform Monte Carlo simulations.

\section{Literature}

The existing literature on Austrian group taxation is mainly written from a tax law perspective ${ }^{5}$. It merely focuses on practical problems like the preconditions for group membership, minimum share requirements, or the choice of the optimal fiscal year. Only a few analytical papers on the investment incentives of group taxation have been published until now ${ }^{6}$. In contrast, the international literature on asymmetric taxation has an economic perspective and emphasises investment effects ${ }^{7}$.

Optimal repatriation and financing strategies of multinational corporations and the optimal legal

5 Cf. Bartl (2004) and, e.g., the articles in Mühlehner/Zöchling (2004).

6 Cf. Pummerer (2004).

7 See, e.g., Barlev/Levy (1975), Auerbach (1986), Auerbach/Poterba (1987), MacKie-Mason (1990). For empirical evidence see, e.g., Altshuler/Auerbach (1990). The literature emphasizes the similarities between the tax claim and a call option. Cf. Ball/Bowers (1982), Majd/Myers (1985), Majd/Myers (1987), Lund (2000). 
structure of foreign activities are major issues in the literature on international taxation ${ }^{8}$. For both decisions, taxation is typically assumed as being symmetrical. In contrast, the literature on asymmetric taxation widely neglects international aspects. The investment effects of loss-offset limitations are rarely analysed in a cross-border setting. Examples are Lyon/Silverstein, who analyse the effects of the U.S. alternative minimum tax on multi-national corporations ${ }^{9}$, and Gérard/Weiner, who focus on loss-offset restrictions under formula apportionment ${ }^{10}$. The impact of group taxation regimes on domestic versus cross-border investment decisions and on real versus financial investment has not been investigated until now.

In this paper, we try to eliminate this shortcoming by simultaneously analysing the investment incentives of the new Austrian group taxation and loss-offset limitations.

\section{Model design}

\subsection{Investment model}

At time $t=0$, an investor with a finite time horizon of $n$ periods decides to invest equity capital $I_{0}$. The investor either acquires a real investment project with cash flows $C F_{t}(t=1, \ldots, n)$ or a financial investment with the constant pre-tax interest rate $i$. In the case of negative cash flows the investor can borrow at the same rate $i$.

The investor (parent company) is an Austrian corporation. It can either invest in the domestic market for its own account or establish a $100 \%$ subsidiary that invests in the foreign country. The choices of location and legal structure at time $t=0$ are irreversible and cannot be revised during the planning period.

By optimally choosing its activities at time $t=0$, the parent company maximises its future value at time $t=n$. The parent company does not pay dividends during the time interval $[0 ; n[$. Profits are fully retained. Thus, all cash flows from real or financial investments are re-invested at the interest rate $i$ until the time horizon $n$ is reached.

In principle, a neutral system of business taxation has to take all taxes on all levels into

8 Cf., e.g., Alworth (1988), Altshuler/Grubert (2002), Gordon/Jun (1993).

9 Cf. Lyon/Silverstein (1995).

10 Cf. Gérard/Weiner (2003). 
account $^{11}$. A complete tax model of a corporate group therefore includes the parent company's taxes, the taxes of all levels of subsidiaries, and taxes of the parent company's shareholders. For reasons of complexity, the parent company's shareholders will be neglected in our model. In a multi-period setting, the optimisation of repatriation policy under asymmetric taxation typically involves non-linear mixed-integer optimisation problems. These problems are notoriously hard to solve, even if group taxation regimes are neglected. To justify our method of procedure, we assume that the investment alternative which yields the maximum future value on the corporate level corresponds to that with the maximum future value on the shareholders' individual level.

\subsection{Tax assumptions}

Our model focuses on the investment effects of group taxation regimes and loss-offset restrictions. We therefore assume that the tax base is defined similarly in both countries. The tax base is calculated as cash flows $C F_{t}$ minus depreciation allowances $\delta_{t}$. Other non-cash accruals shall not exist ${ }^{12}$. Credit (debit) interest payments are fully taxable (tax-deductible) at the usual $\operatorname{tax}_{\text {rate }}{ }^{13}$. As a pre-stage towards the tax base, the earnings of a group member ${ }^{14}$ are denoted by $E_{t}{ }^{15}$. In addition, the parent company may have exogenously-given domestic income denoted by $D E_{t}$, which may be positive or negative. Since $D E_{t}$ is included in taxable income, it is relevant for loss-offset limitations. Hence, the level of $D E_{t}$ may influence the group taxation's effectiveness.

$$
\begin{aligned}
& E_{t}^{P}=C F_{t}-\delta_{t}+I n t_{t}^{P}+D E_{t} \\
& E_{t}^{S}=C F_{t}-\delta_{t}+I n t_{t}^{S},
\end{aligned}
$$

where $I n t_{t}$ denotes the interest income realised by the parent $(\mathrm{P})$ or subsidiary $(\mathrm{S})$.

To isolate the effects of group taxation under limited loss-offset, we assume identical rules for depreciation allowances $\delta_{t}$ in both countries. In accordance with Austrian tax law, linear

11 Cf. Scholes et al. (2005).

12 Depreciation allowances on the subsidiary's book value are neglected because these items are non-deductible under the exemption method in both the domestic and cross-border case.

13 For corporations, the withholding tax on interest income (Kapitalertragsteuer) is not a final tax. There are no tax allowances.

14 Cf. $\S 9$ (6) no. 1 KStG (Austrian corporate income tax code).

15 Superscripts ${ }^{P}$ denote variables related to the parent company, superscripts ${ }^{S}$ relate to the foreign subsidiary. 
depreciation allowances are granted for an economic life of $n$ periods ${ }^{16}$. If a group member only realises financial investment, its earnings $E_{t}$ only consist of interest income: $C F_{t}=\delta_{t}=0$; $E_{t}=\operatorname{Int}_{t}\left(+D E_{t}\right)$.

There are two alternatives for taxing corporate groups: separate taxation and group taxation. If the parent company does not opt for group taxation, the parent company and the subsidiary are taxed separately. The subsidiary's earnings or losses are not taxed in the parent company's home country, as in this case the exemption method applies. In contrast, if a tax group is established, the subsidiary’s losses can be set off against the parent company’s domestic profits, but not vice versa. The preliminary sum of earnings $S_{0} E_{t, p r e}$ prior to subsequent taxation is calculated as follows:

$$
\begin{aligned}
S o E_{t, p r e}^{P} & =E_{t}^{P}+I_{(0,1)}^{L} \cdot \min \left\{0 ; E_{t}^{S}\right\} \\
S o E_{t}^{S} & =E_{t}^{S} .
\end{aligned}
$$

$I_{(0,1)}^{L}$ is a binary variable that indicates whether group taxation is applied $\left(I_{(0,1)}^{L}=1\right)$ or not $\left(I_{(0,1)}^{L}=0\right)$. In our model, the option for group taxation is assumed irreversible ${ }^{17}$.

If the foreign subsidiary incurs losses, the foreign country typically grants a tax loss carryforward. The subsidiary's loss carry-forwards can be set off against its own future profits (loss deduction). Under group taxation, the parent company has to make up for the subsidiary's loss deduction in order to prevent a double loss-offset. The parent company's domestic taxable income therefore increases by the former loss-offset. This procedure is called subsequent taxation. Subsequent taxation ensures that foreign losses are set off exactly once: At the first stage, the foreign loss is set off against domestic profits. At the second stage, the foreign subsidiary carries forward its remaining loss while subsequent taxation takes place in the domestic country ${ }^{18}$. The same sequence applies for losses of foreign branches which are exempted according to double taxation agreements ${ }^{19}$.

In contrast to foreign losses, foreign profits are not recognised but have to be exempted from

16 Cf. $\S 7$ (1) EStG (Austrian individual income tax code; widely applicable to corporations, too).

17 According to $\S 10$ (10) KStG, a tax group must be constituted for at least 3 years. Due to transaction costs, frequent changes of a tax group's composition are unlikely.

18 Cf. Treisch (2004), pp. 238 ff., $261 \mathrm{ff}$. for loss-offset with subsequent taxation.

19 Cf. verdict by Austria’s supreme court (VwGH-cognizance 25.9.2001, 99/14/0217 E, Internationales Steuerrecht 2001, 754, RL 7605 ff. EStR (Austrian individual income tax code instructions). 
domestic taxation ${ }^{20}$. Dividends paid by the foreign subsidiary remain tax-free in the parent company's home state ${ }^{21}$.

The current loss deduction - use of loss carry-forwards in the current period - is defined as the difference between the sum of earnings $S o E_{t}$ and the tax base $T B_{t}$, and is denoted by $L D_{t}: L D_{t}=S o E_{t}-T B_{t}$. Taking subsequent taxation into account, the parent company's (final) sum of earnings can be computed as:

$$
S o E_{t}^{P}=E_{t}^{P}+I_{(0,1)}^{L} \cdot \min \left\{0 ; E_{t}^{S}\right\}+I_{(0,1)}^{L} \cdot \max \left\{0 ; L D_{t}^{S}\right\}
$$

Since 2001, Austrian tax law has restricted loss deductions. The use of loss carry-forwards is limited to $75 \%$ of the current sum of earnings ${ }^{22}$. This provision implies a minimum tax base $\mathrm{e}^{23}$ of at least $\alpha=25 \%$ of positive profits, regardless of existing loss carry-forwards. A time limit for loss carry-forwards does not exist ${ }^{24}$. As a result, the tax base $T B_{t}$ is defined as the maximum of the sum of earnings minus loss carry-forward at the beginning of the period, and the minimum taxable fraction of profits. If the sum of earnings is negative, the tax base equals zero:

$$
T B_{t}=\max \left\{0 ; S o E_{t}-L C_{t-1} ; \alpha \cdot S o E_{t}\right\}
$$

Here, $L C_{t}$ denotes the loss carry-forward at the end of period $t$.

We assume that the foreign country does not apply a minimum tax. With the foreign corporate tax rate $\tau^{S}$ being proportional, the subsidiary's tax payment $T_{t}^{S}$ is: $T_{t}^{S}=\tau^{S} \cdot T B_{t}^{S}$. According to EU law, withholding taxes (Kapitalertragsteuer) neither exist on dividends nor on liquidation proceeds ${ }^{25}$. Hence, the parent company's tax payment $T_{t}^{P}$ amounts to: $T_{t}^{P}=\tau^{P} \cdot T B_{t}^{P}$.

20 For domestic group members, full integration of profits and losses is obligatory.

21 Cf. $\S 10$ (2, 3) KStG. Minimum holding periods do not exist (option right; Article 3 (2) 2. alternative P-S-D. PS-D: Parent-Subsidiary-Directive. Council Directive of 23 July 1990 on the common system of taxation applicable in the case of parent companies and subsidiaries of different Member States (90/435/EEC), OJ 1990, L 225/6-9, amended in OJ 1990, L 266/20. Changed by Directive 2003/123/EC of 22.12.2003, OJ 2004, L 7/4144.). Profits and losses from liquidating subsidiaries are taxed asymmetrically under Austrian tax law. Profits from liquidations are tax-exempt like dividends ( $§ 10(2) \mathrm{KStG}$ ). Losses from liquidations can be deducted as far as they exceed tax-free dividends received in the previous 5 years ( $\S 10$ (3) KStG).

22 Cf. § 27 (2) KStG in connection with § 2 (2b) EStG.

23 This type of minimum tax should not be confused with the U.S. alternative minimum tax, which is a parallel tax system with its own tax base and tax rate.

24 Until 1990, Austria applied a time limit on loss carry-forwards of 7 years.

25 Art. 5 (1) P-S-D. We neglect the special treatment of distributions following a liquidation, which are explicitly exempted from P-S-D (article 4 (1) P-S-D). We assume that the home state of the subsidiary does not levy a withholding tax on liquidation proceeds. 


\subsection{Measuring tax effects}

As stated above, the parent company maximises its future value at the time horizon $t=n$. Consequently, the investment effects of the group taxation and loss-offset limitations are quantified by differences in future values. The future value of an investment alternative is given by the final account balance $F I_{n}$, which is calculated on the basis of a cash flow statement:

$$
\begin{aligned}
F I_{0}^{S} & =0 \\
F I_{t}^{S} & =F I_{t-1}^{S}+I n t_{t}^{S}+C F_{t}-T_{t}^{S}-D_{t}^{S} \\
& =(1+i) \cdot F I_{t-1}^{S}+C F_{t}-T_{t}^{S}-D_{t}^{S} .
\end{aligned}
$$

$D_{t}^{S}$ denotes the dividends paid by the subsidiary. If financial investment is chosen in $t=0$, the account balance is reduced to:

$$
\begin{aligned}
& F I_{0}^{S}=I_{0} \\
& F I_{t}^{S}=(1+i) \cdot F I_{t-1}^{S}-T_{t}^{S}-D_{t}^{S} .
\end{aligned}
$$

Dividend restrictions imposed by financial accounting are taken into account ${ }^{26}$. Thus, the subsidiary can only pay dividends if the financial accounting statement displays a profit and if there is no loss carry-forward. The repatriation policy is determined by the difference in the nominal tax rates: Profits are fully distributed if the foreign corporate tax rate exceeds the domestic one. Otherwise, profits are retained until the time horizon $t=n$. Technically, the dividend payments are defined as follows:

$$
D_{t}^{S}= \begin{cases}\max \left\{0 ; S o E_{t}^{S}-T_{t}^{S}-L C_{t-1}^{S}\right\} & \text { if } \tau^{S}>\tau^{P} \wedge L C_{t}^{S}=0 \\ 0 & \text { otherwise }\end{cases}
$$

The subsidiary is liquidated at the time horizon $t=n$. Then, its account balance $F I_{n}^{S}$ is distributed to the parent company ${ }^{27}$. Liquidating the subsidiary does not induce an additional tax payment in the foreign country because all profits have already been subject to tax.

A remaining loss carry-forward at the time horizon $t=n$ can no longer be set off. For computing the future value, however, it is included by means of a lump-sum valuation. Although the parent

26 In Austria, financial accounting has an authoritative function for tax purposes for most items.

27 The parent company pays for possible debts of the subsidiary. 
company terminates its economic activities at $t=n$, other taxpayers might still utilise its loss carry-forward, at least to a limited degree. In our simulations, remaining loss carry-forwards of the parent company and the subsidiary are valued at $\beta=40 \%$ of face value ${ }^{28}$. This means that the parent company receives a virtual cash receipt of $\beta \cdot \tau \cdot L C_{n}$.

Computing the parent company's future value requires a separate cash flow statement. The parent company's balance account at time $t$ amounts to:

$$
\begin{aligned}
& F I_{0}^{P}=0 \\
& F I_{t}^{P}=F I_{t-1}^{P}+C F_{t}+I n t_{t}^{P}-T_{t}^{P}+D_{t}^{S}+D E_{t} .
\end{aligned}
$$

The future value at the time horizon $F V_{n}^{P}$ is defined as the sum of the balance account and the loss carry-forwards valued on a lump-sum basis:

$$
F V_{n}^{P}=F I_{n}^{P}+\beta \cdot\left(\tau^{P} \cdot L C_{n}^{P}+\tau^{S} \cdot L C_{n}^{S}\right)
$$

Under Austrian tax law, profits from liquidating a subsidiary are tax-exempt ${ }^{29}$. Liquidation losses are tax-deductible, however, if they exceed the last 5 years' tax-free dividends. Hence, the parent company's total tax payment in the final period $t=n$ is given by:

$$
T_{n}^{P}=\max \left\{0 ; \tau^{P} \cdot\left(T B_{n}^{P}+\min \left\{0 ; F I_{n}^{S}-I_{0}+\sum_{t=n-5}^{n} D_{t}^{S}\right\}\right)\right\} .
$$

\section{Monte Carlo simulations}

\subsection{Model setup}

Modelling loss-offset limitations and group taxation rules requires integrating non-linear and state-dependent algebraic functions. Thus, closed-form solutions of the underlying investment problem are unlikely. Even analysing two or three periods is too complicated ${ }^{30}$. Numerical simulations based on cash flow statements, however, can be easily applied. In order to extract

28 Empirical evidence indicates that loss carry-forwards were sold at 25\% of face value in Germany in 1987 . Cf. Schneider (1988), p. 1222. At the former corporate tax rate of about $60 \%$, this fraction implies a $\beta$-value of approximately 0.4 .

29 Cf. $\S 10$ (3) KStG.

30 This is even true for asymmetric taxation of profits and losses in the domestic case. See, e.g., Niemann (2004). 
representative information from numerical cash flow statements, cash flows are modelled as random variables. Projects with different cash flow structures and different expected rates of return are influenced differently by loss-offset restrictions and group taxation regimes. For this reason, it is necessary to vary these parameters.

We start our analysis with a deterministic value for the initial cash flow $C F_{0}$ and assume that the increments $\varepsilon_{t}$ from period $t-1$ to period $t$ are independent and identically distributed with mean $\mu$ and variance $\sigma^{2}:^{31}$

$$
C F_{t}-C F_{t-1}=\varepsilon_{t} \sim \underset{\text { iid }}{\sim} N\left(\mu, \sigma^{2}\right) \quad t=1, \ldots, n \text {. }
$$

Varying the mean $\mu$ results in different cash flow structures. Cash flows that are expected to increase (decrease) over time are represented by $\mu>0 \quad(\mu<0)$. The effects of loss-offset limitations are also determined by a project's expected rate of return. As infra-marginal projects are unlikely to suffer losses, group taxation regimes and loss-offset rules will have little impact on infra-marginal projects. Expected marginal projects, in contrast, are characterised by a higher probability for losses. This means that loss-offset rules may influence investment decisions. Consequently, the following simulations are based on marginal (infra-marginal) projects with expected rates of return of $10 \%(20 \%)$.

Since nominal tax rates have a decisive impact on international location decisions, we differentiate between high-tax and low-tax foreign countries. In our simulations, the high-tax country levies a nominal tax rate of $\tau^{s}=38 \%$, reflecting the combined corporate and municipal tax rate in Germany. In the low-tax country, the tax rate is $\tau^{s}=19 \%$, which, e.g., applies for Slovakia.

Whether a tax group should be established crucially depends on the level of domestic income. This is especially true for holding companies without domestic operating activities, because filing for foreign losses is pointless without domestic profits. We therefore simulate exogenously-given domestic income $D E_{t}$ at a level of $-50,000,0$, and $+50,000$ p.a. ${ }^{32}$ Additional parameters applied in the simulations are:

31 Cf. Niemann (2004), p. 14.

32 There are no current loss carry-forwards at the time of investment $t=0$. 


\begin{tabular}{ll}
\hline Equity = initial outlay & $I_{0}=1,000,000$ \\
\hline Pre-tax interest rate & $i=0.1$ \\
\hline Number of simulated cash flows for each set of parameters & $s=25,000$ \\
\hline Time horizon & $n=10$ \\
\hline Standard deviation of the increments $\varepsilon_{t}$ & $\sigma=50,000$ \\
\hline
\end{tabular}

Table 1: Parameters of the executed simulations

Four different future values are computed in each simulation. First, domestic real investment in the parent company is compared to foreign real investment in the subsidiary. Second, domestic financial investment in the parent company is compared to foreign financial investment in the subsidiary. Finally, the investor realises the alternative with the maximum future value.

Each simulation is carried out without $\left(I_{(0,1)}^{L}=0\right)$ and with group taxation $\left(I_{(0,1)}^{L}=1\right)$. The group taxation's investment effects are quantified by the compiled distributions of future values.

Moreover, we analyse the influence of repatriation policy in the case of positive exogenous domestic income. We compare the difference in future values for retaining profits with and without group taxation to the difference in future values for distributing profits with and without group taxation. The resulting changes in future values represent the group taxation's investment incentives depending on the dividend policy.

\subsection{Simulation results}

Decision between domestic and foreign financial investment

Since interest yield is deterministic and always positive, group taxation regimes do not influence decisions between domestic financial investment in the parent company and foreign financial investment in the subsidiary. Financial investments are always carried out in the lower-tax country. 
Decision between domestic and foreign real investment

As expected, the nominal tax rates also determine the decision between domestic real investment in the parent company and foreign real investment in the subsidiary. The impact of group taxation on domestic versus foreign real investment, however, is ambiguous. Whether group taxation or separate taxation is chosen crucially depends on the expected structure of cash flows and the level of domestic income.

We were surprised by the results for expected marginal investment with increasing cash flows, which are often associated with innovative projects. The parameter setting under consideration is $C F_{0}=-309,801, \mu=100,000$. Without exogenously-given domestic income $\left(D E_{t}=0\right)$, opting for group taxation reduces the arithmetic mean of the future value of real investment in the foreign subsidiary. The reduction can amount to as much as 1.27\% (from 2,261,751 to 2,233,054 for $\tau^{S}=19 \%$ ). This apparently paradoxical effect results from the initial losses that frequently arise in this parameter setting. In principle, these foreign initial losses could be set off against domestic profits, if there had been any. In our case, however, the group taxation only generates a domestic loss carry-forward, which in future periods is subject to the loss deduction limit of $75 \%$ of current profits ${ }^{33}$. The parent company therefore has to pay taxes even in the presence of loss carry-forwards.

This effect is not primarily caused by the lump-sum valuation of expiring loss carry-forwards. It also occurs, e.g., for $\beta=0.8$. The average future value decreases from 2,280,462 without group taxation to 2,279,506 with group taxation. A reduction may even occur for the maximal, but unrealistic value of $\beta=1$. This kind of group taxation paradox could not occur without the lossdeduction limit ${ }^{34}$.

For sufficiently high levels of domestic income, which prevent domestic loss carry-forwards, these paradoxes do not occur. The group taxation induces an average increase of future values of up to $2.2 \%$ (for $D E_{t}=50,000, \tau^{s}=38 \%$ ).

If expected marginal projects with constant cash flows are considered $\left(C F_{0}=162,745, \mu=0\right)$, group taxation only provides negligible investment incentives. The average increase in future values that is attributable to group taxation amounts to $0.5 \%-1.2 \%$. This effect is widely

34 See also Pummerer (2004), p. 14. He does not, however, distinguish between different cash flow structures and 
independent of the foreign corporate tax rate and the level of domestic income. Since domestic real investment is unaffected by the group taxation regime, the average difference in future values of foreign and domestic real investment increases accordingly.

For expected marginal projects with decreasing cash flows $\left(C F_{0}=399,018, \mu=-50,000\right)$, the average increase in the future values is far more pronounced, especially for the foreign high-tax country. For the parameter setting $D E_{t}=0, \tau^{s}=38 \%$, group taxation induces an average increase in the future values of $\frac{1,788,164.03}{1,717,394.86}-1=4.12 \%$. In the presence of exogenous domestic losses $\left(D E_{t}=-50,000\right)$, the increase even amounts to $\frac{1,162,585.85}{1,114,838.34}-1=4.28 \%$. Due to group taxation, the fraction of foreign projects which yield a higher future value than an identical domestic project increases from $14.46 \%$ to $27.15 \%\left(D E_{t}=0, \tau^{S}=38 \%\right)$. In the 25,000 cases, however, real investment is never realised in the foreign subsidiary, because domestic financial investment yields an even higher future value. Despite the substantial increase in the average future value the investment decision remains unchanged.

Looking at expected infra-marginal projects with increasing cash flows $\left(C F_{0}=-84,043, \mu=100,000\right)$, group taxation paradoxes can be observed, too $\left(D E_{t}=0\right)$. The average reduction of the future value, however, only amounts to $0.2 \%$. For positive exogenous domestic income $\left(D E_{t}=50,000\right)$, group taxation leads to an average increase in future values of up to $0.1 \%$. For expected infra-marginal projects with constant cash flows $\left(C F_{0}=388,503, \mu=0\right)$, the positive impact of group taxation is in the $0.01 \%$ region. For expected infra-marginal projects with decreasing cash flows $\left(C F_{0}=624,776, \mu=-50,000\right)$, the average increase in future values amounts to less than $0.3 \%$. Group taxation never alters the decision between domestic and foreign real investment in this parameter setting. The negligible magnitude of the investment incentives leads to the conclusion that group taxation regimes may be almost irrelevant to expected infra-marginal projects.

\section{Decision between optimal real investment and optimal financial investment}

With regard to the decision between value-maximising real investment and value-maximising financial investment, the effects of group taxation are ambiguous. For expected marginal projects 
with constant or decreasing cash flows, the arithmetic mean of the difference of future values increases in all parameter settings. In contrast, the effects are ambiguous for expected increasing cash flows: Group taxation lowers the mean difference of future values for the low-tax foreign country and raises the mean difference of future values for the high-tax foreign country if domestic income is non-positive.

In the case of the low-tax foreign country, the reason for the decrease of the average difference of future values is that foreign profits are tax-exempt and cannot be set off against domestic $\operatorname{losses}^{35}$. Domestic loss-offset potential can only be used if domestic investment is carried out or if foreign profits are repatriated. In many cases, domestic loss-offset potential compensates for the higher domestic tax rate ( $25 \%$ instead of $19 \%$ abroad). It may therefore pay off to realise investment in the parent company.

In contrast, the average difference in future values can increase substantially, assuming positive exogenous domestic income. This result does not depend on the nominal tax rates.

If the fraction of positive differences in future values is considered, introducing group taxation does not induce significant effects. As a consequence, group taxation seems to offer only marginal incentives for real investments.

As could be expected, group taxation is almost irrelevant to expected infra-marginal projects. It induces changes of the average difference of future values between optimal real and optimal financial investment of between $+0.3 \%$ and $-0.3 \%$.

\section{Relevance of repatriation policy}

According to equation (7), we assumed that the subsidiary's distribution policy is exclusively determined by nominal tax rates: Profits are fully distributed if the foreign corporate tax rate exceeds the domestic one. Otherwise, all profits are retained until the time horizon $t=n$. In a multi-period setting, such a simple decision rule may produce suboptimal future values as soon as exogenous domestic losses coincide with low foreign tax rates. The domestic losses cannot be set off against tax-exempt foreign profits and accumulate to the domestic loss carry-forward. Since the profit from liquidating the foreign subsidiary is also tax-exempt, the domestic loss

35 If the exogenous domestic income is non-negative, losses do not occur, and domestic and foreign income is taxed separately. Hence, the choice of location follows the lower nominal tax rate. 
carry-forward can only be valued at the lump-sum fraction $\beta$.

Despite the higher domestic tax rate, it can be efficient to repatriate profits generated by the foreign subsidiary in order to use the domestic loss-offset potential. Although the dividends are tax-exempt, the positive interest income resulting from re-invested dividends can be set off against domestic losses in future periods.

For this reason, we carried out simulations in the parameter setting $D E_{t}=-50,000 ; \tau^{S}=19 \%$ for full distribution as well as for full retention of profits. In all parameter combinations, the distribution of profits dominated retention. Full distribution, however, is not necessarily optimal in all settings. Finding the globally optimal repatriation policy requires the optimisation of all $n$ continuous dividend payments, allowing for restrictions from financial accounting. Due to the non-linear algebraic functions induced by asymmetric taxation, these optimisation problems are quite complex. Typically, only approximative solutions can be found by direct search methods with numerous iterations. In the case of Monte Carlo simulations, these methods are not feasible for a sufficient sample size.

Moreover, the impact of repatriation policy on the effectiveness of the group taxation regime is ambiguous. We computed the change in the mean difference of future values with and without group taxation which is attributable to improved distribution policy. For expected marginal projects with increasing cash flows $\left(C F_{0}=-309,801, \mu=100,000\right)$, the average future value is reduced by group taxation. For full distribution, group taxation causes a reduction of the average future value, which is 44 less than for full retention. For expected marginal projects with constant cash flows $\left(C F_{0}=162,745, \mu=0\right)$, group taxation increases the average future value. For full distribution, the increase of the average future value is 1,416 higher than for full retention. For expected marginal projects with decreasing cash flows $\left(C F_{0}=399,018\right.$, $\mu=-50,000)$ the increase of the average future value resulting from group taxation is even 22,741 higher than for full retention. As a consequence, improving the dividend policy seems to strengthen the group taxation's effectiveness, as can be seen from table 2: 


\begin{tabular}{lccr}
\hline $\begin{array}{l}\text { Change in future values of } \\
\text { expected marginal projects due to } \\
\text { group taxation }\end{array}$ & $\begin{array}{l}\text { In the case of } \\
\text { retained profits }\end{array}$ & $\begin{array}{l}\text { In the case of } \\
\text { distributed profits }\end{array}$ & $\begin{array}{l}\text { Additional influence of } \\
\text { group taxation regimes } \\
\text { resulting from a modified } \\
\text { dividend policy }\end{array}$ \\
\hline & $(1)$ & $(2)$ & $(2)-(1)$ \\
\hline with increasing cash flows & $-12,318$ & $-12,274$ & +44 \\
with constant cash flows & $+10,808$ & $+12,224$ & $+1,416$ \\
with decreasing cash flows & $+27,201$ & $+49,942$ & $+22,741$ \\
\hline
\end{tabular}

Table 2: Correlation between dividend policy and group taxation

In this parameter setting, the domestic loss-offset potential compensates for the domestic tax rate (25\%) which is higher than the foreign tax rate (19\%). Obviously, there is a trade-off between nominal tax rates and loss-offset potential. Investors are well advised to decide simultaneously upon repatriation policy and the option for group taxation.

Dividend restrictions from financial accounting also affect the group taxation's effectiveness. In general, dividend restrictions in the presence of loss carry-forwards discriminate against real investment in the foreign subsidiary. It is obvious that additional restrictions tend to reduce future values. The average reduction of the future value differs, however, depending on whether group taxation is applied or not. Substantial differences can only be observed for projects with starting losses, because loss carry-forwards exclude dividends. For expected marginal projects with increasing cash flows $\left(C F_{0}=-309,801, \mu=100,000\right)$, table 3 denotes the average future values for the parameters $D E_{t}=0$ and $\tau^{S}=38 \%$. Obviously, the disadvantage from dividend restrictions is higher when group taxation is applied.

\begin{tabular}{lrrr}
\hline $\begin{array}{l}\text { Future value of real } \\
\text { investment in the foreign } \\
\text { subsidiary }\end{array}$ & $\begin{array}{l}\text { Without dividend } \\
\text { restriction in the case of } \\
\text { loss carry-forwards }\end{array}$ & $\begin{array}{l}\text { With dividend restriction } \\
\text { in the case of loss carry- } \\
\text { forwards }\end{array}$ & $\begin{array}{l}\text { Disadvantages } \\
\text { resulting from } \\
\text { dividend restrictions }\end{array}$ \\
\hline Under separate taxation & $1,976,287$ & $1,941,172$ & 35,115 \\
Under group taxation & $1,974,462$ & $1,922,485$ & 51,977 \\
\hline $\begin{array}{l}\text { Disadvantages resulting } \\
\text { from group taxation }\end{array}$ & $-1,825$ & $-18,687$ & Difference: $-16,862$ \\
\hline
\end{tabular}

Table 3: Correlation between dividend restrictions and group taxation

For projects with expected constant or decreasing cash flows, the group taxation's effectiveness 
remains widely unchanged by dividend restrictions. Again, this example indicates that deciding on group taxation requires the consideration of all known parameters as well as the foreign financial accounting rules. In any case, an arbitrary consolidation of all foreign subsidiaries may prove financially detrimental.

\section{Summary and conclusion}

When evaluating the Austrian group taxation, it should be emphasised that the investment incentives strongly depend on the parameter setting under consideration. The most important determinants are a project's expected rate of return and its expected structure of cash flows. The magnitude of the group taxation's investment incentives is summarised in table 4:

\begin{tabular}{lcccc}
\hline \multirow{2}{*}{$\begin{array}{l}\text { Degree of influence of group taxation } \\
\text { regimes on investment decisions }\end{array}$} & \multicolumn{3}{c}{ Expected cash flows } \\
\cline { 3 - 5 } & Increasing & Constant & Decreasing \\
\hline $\begin{array}{l}\text { expected rate of } \\
\text { return }\end{array}$ & marginal & average & low & relatively high \\
& high & very low & very low & very low \\
\hline
\end{tabular}

Table 4: Relevance of group taxation regimes for investment decisions

Hence, sensible planning for the establishment of a tax group requires detailed assumptions on the possible activities. Obviously, the group taxation's investment incentives should not be overestimated. The future values of the different investment alternatives vary too slightly to cause substantial shifts in investment behaviour. A promotion of real investment seems unlikely.

The dividend policy should be taken into account when deciding whether or not to opt for group taxation. Even for subsidiaries in low-tax jurisdictions, immediate repatriation of profits can be efficient to use domestic loss-offset potential. In many cases, there is a trade-off between tax rates and loss-offset rules, which means that improved loss-offset potential can compensate for a higher nominal tax rate.

Innovative projects often generate initial losses. Since the Austrian loss deduction limit tends to cause group taxation paradoxes, it is not yet clear to which extent the taxpayers will opt for the group taxation. Comprehensive tax planning explicitly requires taking exogenous domestic income into account. For holding companies without a domestic operating business, group taxation seems almost irrelevant, because the dividends received by these corporations are tax- 
exempt in Austria $^{36}$ and hence cannot be set off against foreign losses.

Tax planning of projects with starting losses requires an especially thorough analysis. Opting for group taxation may prove harmful in the presence of dividend restrictions from financial accounting. As a consequence, investors are well advised to plan a project's expected rate of return, its expected structure of cash flows, domestic taxable income and the optimal repatriation policy simultaneously prior to establishing a tax group.

In the light of the model's complexity, some real-world problems have been neglected here and should be subject to further analysis. Integration of the parent company's shareholders and their taxation poses one of these problems. Since these shareholders may be domestic or foreign natural persons or corporations, a variety of different cases with different tax consequences may arise.

Apart from the location decision, the parent company can use various other tax minimising strategies that we neglected in our model such as, for example, financing policy. As we assume equity-financed investments, the only possibility to partially avoid the loss deduction limit for the parent company is to pay out dividends. In contrast, if the parent company finances the foreign subsidiary with debt instead of equity, the loss deduction limit can be avoided easily. Possible thin capitalisation rules have to be taken into account, however, when choosing debt finance.

Summarising, Austrian group taxation is an interesting step towards an integrated taxation of corporate groups, especially with regard to the European Court of Justice's AMID verdict ${ }^{37}$ that demands cross-border loss-offset within the EU. Our analysis, however, shows ambiguous results. In any case, investors are well advised to use multi-period models of capital budgeting, preferably for different settings of the state variables.

\section{Appendix: Simulation results}

36 Cf. § $10(2,3) \mathrm{KStG}$.

37 Cf. European Court of Justice, judgement of 14.12.2000, Case C-141/99 (AMID), EuGHE 2000 I, 11619; VwGH-findings of 25.9.2001, 99/14/0217 E, Internationales Steuerrecht 2001, 754; RL 7605 ff. EStR. 


\begin{tabular}{|c|c|c|c|c|c|c|c|c|c|c|c|c|}
\hline \multicolumn{5}{|c|}{ Parameters } & \multicolumn{4}{|c|}{ Arithmetic mean of future values } & \multirow{2}{*}{$\begin{array}{c}\text { Increase in future } \\
\text { value due to } \\
\text { group taxation }\end{array}$} & \multirow{2}{*}{$\begin{array}{c}\text { Change in future } \\
\text { value } \\
\text { domestic-foreign } \\
\text { real investment }\end{array}$} & \multirow{2}{*}{$\begin{array}{c}\text { Domestic } \\
\text { real } \\
\text { investment } \\
\text { better than } \\
\text { foreign real } \\
\text { investment }\end{array}$} & \multirow{2}{*}{$\begin{array}{l}\text { Average difference in } \\
\text { future value } \\
\text { opt. real investment } \\
\text { - opt. financial } \\
\text { investment }\end{array}$} \\
\hline$\mu$ & $C F_{0}$ & $D E_{t}$ & $\tau^{S}$ & $I_{(0,1)}^{L}$ & $\begin{array}{c}\text { domestic } \\
\text { financial } \\
\text { investment }\end{array}$ & $\begin{array}{c}\text { foreign } \\
\text { financial } \\
\text { investment }\end{array}$ & $\begin{array}{c}\text { domestic } \\
\text { real } \\
\text { investment }\end{array}$ & $\begin{array}{c}\text { foreign } \\
\text { real } \\
\text { investment }\end{array}$ & & & & \\
\hline 0 & 162,745 & 0 & $19 \%$ & 0 & $2,061,032$ & $2,178,999$ & $2,043,935$ & $2,187,668$ & & $-143,733$ & $0.00 \%$ & 8,670 \\
\hline 0 & 162,745 & 0 & $19 \%$ & 1 & $2,061,032$ & $2,178,999$ & $2,043,935$ & $2,197,778$ & $0.462 \%$ & $-153,843$ & $0.26 \%$ & 18,785 \\
\hline 0 & 162,745 & 0 & $38 \%$ & 0 & $2,061,032$ & $1,877,119$ & $2,043,935$ & $1,863,110$ & & 180,825 & $86.40 \%$ & 1,670 \\
\hline 0 & 162,745 & 0 & $38 \%$ & 1 & $2,061,032$ & $1,877,119$ & $2,043,935$ & $1,877,039$ & $0,748 \%$ & 166,896 & $84.76 \%$ & 13,881 \\
\hline 0 & 162,745 & $-50,000$ & $19 \%$ & 0 & $1,530,516$ & $1,525,654$ & $1,458,830$ & $1,522,805$ & & $-63,975$ & $33.00 \%$ & 5,294 \\
\hline 0 & 162,745 & $-50,000$ & $19 \%$ & 1 & $1,530,516$ & $1,525,654$ & $1,458,830$ & $1,535,030$ & $0.803 \%$ & $-76,199$ & $32.57 \%$ & 17,347 \\
\hline 0 & 162,745 & $-50,000$ & $38 \%$ & 0 & $1,530,516$ & $1,234,124$ & $1,458,830$ & $1,211,631$ & & 247,199 & $84.48 \%$ & $-44,493$ \\
\hline 0 & 162,745 & $-50,000$ & $38 \%$ & 1 & $1,530,516$ & $1,234,124$ & $1,458,830$ & $1,223,856$ & $1.009 \%$ & 234,974 & $83.76 \%$ & $-33,220$ \\
\hline 0 & 162,745 & 50,000 & $19 \%$ & 0 & $2,591,547$ & $2,709,514$ & $2,597,678$ & $2,720,073$ & & $-122,394$ & $10.16 \%$ & 12,985 \\
\hline 0 & 162,745 & 50,000 & $19 \%$ & 1 & $2,591,547$ & $2,709,514$ & $2,597,678$ & $2,745,406$ & $0.931 \%$ & $-147,727$ & $0.00 \%$ & 35,891 \\
\hline 0 & 162,745 & 50,000 & $38 \%$ & 0 & $2,591,547$ & $2,407,635$ & $2,597,678$ & $2,396,073$ & & 201,605 & $96.17 \%$ & 9,663 \\
\hline 0 & 162,745 & 50,000 & $38 \%$ & 1 & $2,591,547$ & $2,407,635$ & $2,597,678$ & $2,425,128$ & $1.213 \%$ & 172,550 & $84.58 \%$ & 31,159 \\
\hline$-50,000$ & 399,018 & 0 & $19 \%$ & 0 & $2,061,032$ & 2,178,999 & 1,903,109 & $2,094,330$ & & $-191,222$ & $0.00 \%$ & $-84,668$ \\
\hline$-50,000$ & 399,018 & 0 & $19 \%$ & 1 & $2,061,032$ & $2,178,999$ & $1,903,109$ & $2,121,495$ & $1.297 \%$ & $-218,387$ & $0.00 \%$ & $-57,503$ \\
\hline$-50,000$ & 399,018 & 0 & $38 \%$ & 0 & $2,061,032$ & $1,877,119$ & $1,903,109$ & $1,717,394$ & & 185,715 & $85.54 \%$ & $-138,701$ \\
\hline$-50,000$ & 399,018 & 0 & $38 \%$ & 1 & $2,061,032$ & $1,877,119$ & 1,903,109 & $1,788,164$ & $4.121 \%$ & 114,945 & $72.85 \%$ & $-101,367$ \\
\hline$-50,000$ & 399,018 & $-50,000$ & $19 \%$ & 0 & $1,530,516$ & $1,461,814$ & $1,308,371$ & $1,377,146$ & & $-68,775$ & $20.60 \%$ & $-148,409$ \\
\hline$-50,000$ & 399,018 & $-50,000$ & $19 \%$ & 1 & $1,530,516$ & $1,461,814$ & $1,308,371$ & $1,404,347$ & $1.975 \%$ & $-95,976$ & $19.51 \%$ & $-121,365$ \\
\hline$-50,000$ & 399,018 & $-50,000$ & $38 \%$ & 0 & $1,530,516$ & $1,234,124$ & $1,308,371$ & $1,114,838$ & & 193,532 & $82.71 \%$ & $-196,113$ \\
\hline$-50,000$ & 399,018 & $-50,000$ & $38 \%$ & 1 & $1,530,516$ & $1,234,124$ & $1,308,371$ & $1,162,586$ & $4.283 \%$ & 145,785 & $75.23 \%$ & $-167,261$ \\
\hline$-50,000$ & 399,018 & 50,000 & $19 \%$ & 0 & $2,591,547$ & $2,709,514$ & $2,472,971$ & $2,627,225$ & & $-154,254$ & $0.54 \%$ & $-82,238$ \\
\hline$-50,000$ & 399,018 & 50,000 & $19 \%$ & 1 & $2,591,547$ & $2,709,514$ & $2,472,971$ & $2,676,281$ & $1.867 \%$ & $-203,311$ & $0.00 \%$ & $-33,233$ \\
\hline$-50,000$ & 399,018 & 50,000 & $38 \%$ & 0 & $2,591,547$ & $2,407,635$ & $2,472,971$ & $2,255,193$ & & 217,777 & $94.04 \%$ & $-112,733$ \\
\hline$-50,000$ & 399,018 & 50,000 & $38 \%$ & 1 & $2,591,547$ & $2,407,635$ & $2,472,971$ & $2,347,497$ & $4.093 \%$ & 125,474 & $75.18 \%$ & $-71,888$ \\
\hline 100,000 & $-309,801$ & 0 & $19 \%$ & 0 & $2,061,032$ & $2,178,999$ & $2,122,241$ & $2,261,751$ & & $-139,510$ & $0.00 \%$ & 82,753 \\
\hline 100,000 & $-309,801$ & 0 & $19 \%$ & 1 & $2,061,032$ & $2,178,999$ & $2,122,241$ & $2,233,054$ & $-1.269 \%$ & $-110,813$ & $8.19 \%$ & 54,812 \\
\hline 100,000 & $-309,801$ & 0 & $38 \%$ & 0 & $2,061,032$ & $1,877,119$ & $2,122,241$ & $1,941,172$ & & 181,069 & $82.98 \%$ & 88,085 \\
\hline 100,000 & $-309,801$ & 0 & $38 \%$ & 1 & $2,061,032$ & $1,877,119$ & $2,122,241$ & $1,922,485$ & $-0.963 \%$ & 199,756 & $85.43 \%$ & 93,221 \\
\hline 100,000 & $-309,801$ & $-50,000$ & $19 \%$ & 0 & $1,530,516$ & $1,461,814$ & $1,493,313$ & $1,544,567$ & & $-51,254$ & $36.64 \%$ & 23,306 \\
\hline 100,000 & $-309,801$ & $-50,000$ & $19 \%$ & 1 & $1,530,516$ & $1,461,814$ & $1,493,313$ & $1,532,250$ & $-0.797 \%$ & $-38,937$ & $50.20 \%$ & 21,523 \\
\hline 100,000 & $-309,801$ & $-50,000$ & $38 \%$ & 0 & $1,530,516$ & $1,234,124$ & $1,493,313$ & $1,241,468$ & & 251,845 & $80.41 \%$ & -286 \\
\hline 100,000 & $-309,801$ & $-50,000$ & $38 \%$ & 1 & $1,530,516$ & $1,234,124$ & $1,493,313$ & $1,229,170$ & $-0.991 \%$ & 264,143 & $81.82 \%$ & 6,017 \\
\hline 100,000 & $-309,801$ & 50,000 & $19 \%$ & 0 & $2,591,547$ & $2,709,514$ & $2,714,980$ & $2,794,064$ & & $-79,084$ & $23.16 \%$ & 92,853 \\
\hline 100,000 & $-309,801$ & 50,000 & $19 \%$ & 1 & $2,591,547$ & $2,709,514$ & $2,714,980$ & $2,847,383$ & $1.908 \%$ & $-132,403$ & $0.00 \%$ & 137,869 \\
\hline 100,000 & $-309,801$ & 50,000 & $38 \%$ & 0 & $2,591,547$ & $2,407,635$ & $2,714,980$ & $2,473,485$ & & 241,495 & $96.10 \%$ & 127,023 \\
\hline 100,000 & $-309,801$ & 50,000 & $38 \%$ & 1 & $2,591,547$ & $2,407,635$ & $2,714,980$ & $2,526,804$ & $2.156 \%$ & 188,176 & $86.81 \%$ & 148,492 \\
\hline
\end{tabular}

Table 5: Arithmetic mean of future value and differences in future values 


\begin{tabular}{|c|c|c|c|c|c|c|c|c|}
\hline \multicolumn{5}{|c|}{ Parameters } & \multicolumn{4}{|c|}{ Frequency of optimal choice of the investment project } \\
\hline$\mu$ & $C F_{0}$ & $D E_{t}$ & $\tau^{S}$ & $I_{(0,1)}^{L}$ & $\begin{array}{c}\text { Domestic } \\
\text { financial } \\
\text { investment }\end{array}$ & $\begin{array}{c}\text { Foreign } \\
\text { financial } \\
\text { investment }\end{array}$ & $\begin{array}{c}\text { Domestic } \\
\text { real } \\
\text { investment }\end{array}$ & $\begin{array}{l}\text { Foreign } \\
\text { real investment }\end{array}$ \\
\hline 0 & 162,745 & 0 & $19 \%$ & 0 & $0.00 \%$ & $49.31 \%$ & $0.00 \%$ & $50,69 \%$ \\
\hline 0 & 162,745 & 0 & $19 \%$ & 1 & $0.00 \%$ & $49.33 \%$ & $0.00 \%$ & $50.67 \%$ \\
\hline 0 & 162,745 & 0 & $38 \%$ & 0 & $49.09 \%$ & $0.00 \%$ & $50.91 \%$ & $0.00 \%$ \\
\hline 0 & 162,745 & 0 & $38 \%$ & 1 & $49.09 \%$ & $0.00 \%$ & $50.91 \%$ & $0.00 \%$ \\
\hline 0 & 162,745 & $-50,000$ & $19 \%$ & 0 & $49.20 \%$ & $0.00 \%$ & $5.94 \%$ & $44.86 \%$ \\
\hline 0 & 162,745 & $-50,000$ & $19 \%$ & 1 & $49.20 \%$ & $0.00 \%$ & $5.94 \%$ & $44.86 \%$ \\
\hline 0 & 162,745 & $-50,000$ & $38 \%$ & 0 & $49.26 \%$ & $0.00 \%$ & $50.74 \%$ & $0.00 \%$ \\
\hline 0 & 162,745 & $-50,000$ & $38 \%$ & 1 & $49.26 \%$ & $0.00 \%$ & $50.74 \%$ & $0.00 \%$ \\
\hline 0 & 162,745 & 50,000 & $19 \%$ & 0 & $0.00 \%$ & $49.31 \%$ & $0.00 \%$ & $50.69 \%$ \\
\hline 0 & 162,745 & 50,000 & $19 \%$ & 1 & $0.00 \%$ & $49.30 \%$ & $0.00 \%$ & $50.70 \%$ \\
\hline 0 & 162,745 & 50,000 & $38 \%$ & 0 & $49.08 \%$ & $0.00 \%$ & $50.92 \%$ & $0.00 \%$ \\
\hline 0 & 162,745 & 50,000 & $38 \%$ & 1 & $49.08 \%$ & $0.00 \%$ & $50.92 \%$ & $0.00 \%$ \\
\hline$-50,000$ & 399,018 & 0 & $19 \%$ & 0 & $0.00 \%$ & $52.54 \%$ & $0.00 \%$ & $47.46 \%$ \\
\hline$-50,000$ & 399,018 & 0 & $19 \%$ & 1 & $0.00 \%$ & $52.40 \%$ & $0.00 \%$ & $47.60 \%$ \\
\hline$-50,000$ & 399,018 & 0 & $38 \%$ & 0 & $53.60 \%$ & $0.00 \%$ & $46.40 \%$ & $0.00 \%$ \\
\hline$-50,000$ & 399,018 & 0 & $38 \%$ & 1 & $53.60 \%$ & $0.00 \%$ & $46.40 \%$ & $0.00 \%$ \\
\hline$-50,000$ & 399,018 & $-50,000$ & $19 \%$ & 0 & $54.60 \%$ & $0.00 \%$ & $11.01 \%$ & $34.39 \%$ \\
\hline$-50,000$ & 399,018 & $-50,000$ & $19 \%$ & 1 & $54.50 \%$ & $0.00 \%$ & $11.00 \%$ & $34.50 \%$ \\
\hline$-50,000$ & 399,018 & $-50,000$ & $38 \%$ & 0 & $55.04 \%$ & $0.00 \%$ & $44.96 \%$ & $0.00 \%$ \\
\hline$-50,000$ & 399,018 & $-50,000$ & $38 \%$ & 1 & $55.04 \%$ & $0.00 \%$ & $44.96 \%$ & $0.00 \%$ \\
\hline$-50,000$ & 399,018 & 50,000 & $19 \%$ & 0 & $0.00 \%$ & $52.54 \%$ & $0.00 \%$ & $47.46 \%$ \\
\hline$-50,000$ & 399,018 & 50,000 & $19 \%$ & 1 & $0.00 \%$ & $52.20 \%$ & $0.00 \%$ & $47.80 \%$ \\
\hline$-50,000$ & 399,018 & 50,000 & $38 \%$ & 0 & $53.27 \%$ & $0.00 \%$ & $46.73 \%$ & $0.00 \%$ \\
\hline$-50,000$ & 399,018 & 50,000 & $38 \%$ & 1 & $53.27 \%$ & $0.00 \%$ & $46.73 \%$ & $0.00 \%$ \\
\hline 100,000 & $-309,801$ & 0 & $19 \%$ & 0 & $0.00 \%$ & $46.36 \%$ & $0.00 \%$ & $53.64 \%$ \\
\hline 100,000 & $-309,801$ & 0 & $19 \%$ & 1 & $0.00 \%$ & $48.03 \%$ & $0.00 \%$ & $51.97 \%$ \\
\hline 100,000 & $-309,801$ & 0 & $38 \%$ & 0 & $45.54 \%$ & $0.00 \%$ & $54.46 \%$ & $0.00 \%$ \\
\hline 100,000 & $-309,801$ & 0 & $38 \%$ & 1 & $45.54 \%$ & $0.00 \%$ & $54.46 \%$ & $0.00 \%$ \\
\hline 100,000 & $-309,801$ & $-50,000$ & $19 \%$ & 0 & $47.76 \%$ & $0.00 \%$ & $18.89 \%$ & $33.34 \%$ \\
\hline 100,000 & $-309,801$ & $-50,000$ & $19 \%$ & 1 & $47.76 \%$ & $0.00 \%$ & $28.34 \%$ & $23.89 \%$ \\
\hline 100,000 & $-309,801$ & $-50,000$ & $38 \%$ & 0 & $47.76 \%$ & $0.00 \%$ & $52.24 \%$ & $0.00 \%$ \\
\hline 100,000 & $-309,801$ & $-50,000$ & $38 \%$ & 1 & $47.76 \%$ & $0.00 \%$ & $52.24 \%$ & $0.00 \%$ \\
\hline 100,000 & $-309,801$ & 50,000 & $19 \%$ & 0 & $0.00 \%$ & $46.36 \%$ & $0.00 \%$ & $53.64 \%$ \\
\hline 100,000 & $-309,801$ & 50,000 & $19 \%$ & 1 & $0.00 \%$ & $45.09 \%$ & $0.00 \%$ & $54.91 \%$ \\
\hline 100,000 & $-309,801$ & 50,000 & $38 \%$ & 0 & $43.91 \%$ & $0.00 \%$ & $56.09 \%$ & $0.00 \%$ \\
\hline 100,000 & $-309,801$ & 50,000 & $38 \%$ & 1 & $43.91 \%$ & $0.00 \%$ & $56.09 \%$ & $0.00 \%$ \\
\hline
\end{tabular}

Table 6: Relative frequency of optimal choice of the investment project 


\section{Literature}

Altshuler, Rosanne / Auerbach, Alan J. (1990): The Significance of Tax Law Asymmetries: An Empirical Investigation, in: Quarterly Journal of Economics 105, 61-89.

Altshuler, Rosanne / Grubert, Harry (2002): Repatriation Taxes, Repatriation Strategies and Multinational Financial Policy, in: Journal of Public Economics 87, 73-107.

Alworth, Julian (1988): The Finance, Investment and Taxation Decisions of Multinationals, Oxford, New York.

Auerbach, Alan J. (1986): The Dynamic Effects of Tax Law Asymmetries, in: Review of Economic Studies 53, 205-225.

Auerbach, Alan J. / Poterba, James M. (1987): Tax Loss Carryforwards and Corporate Tax Incentives, in: Feldstein, Martin (ed.): The Effects of Taxation on Capital Accumulation, Chicago, 305-338.

Ball, Ray / Bowers, John (1982): Distortions Created by Taxes Which are Options on Value Creation: The Australian Resources Rent Tax Proposal 1982, in: Australian Journal of Management 8/2, 1-14.

Barlev, Benzion / Levy, Haim (1975): Loss Carryback and Carryover Provision: Effectiveness and Economic Implications, in: National Tax Journal 28, 173-184.

Bartl, Georg (2004): Die Besteuerung von Unternehmensgruppen ab 2005, in: Finanz Journal 43, 179-184.

Gassner, Wolfgang / Haidenthaler, Werner (2004): Group Taxation in Austria, Steuer und Wirtschaft International 14, 434-440.

Gérard, Marcel / Weiner, Joann (2003): Cross-Border Loss Offset and Formulary Apportionment: How do they Affect Multijurisdictional Firm Investment Spending and Interjurisdictional Tax Competition? CESifo Working Paper No. 1004.

Gordon, Roger H. / Jun, Joosung (1993): Taxes and the Form of Ownership of Foreign Corporate Equity, in: Giovannini, Alberto / Hubbard, R. Glenn / Slemrod, Joel (eds.): Studies in International Taxation, Chicago, 13-44.

Lund, Diderik (2000): Imperfect loss offset and the after-tax expected rate of return to equity, 
with an application to rent taxation, Memorandum No. 21/2000, Department of Economics, University of Oslo.

Lyon, Andrew B. / Silverstein, Gerald (1995): The Alternative Minimum Tax and the Behaviour of Multinational Corporations, in: Feldstein, Martin (ed.): The Effects of Taxation on Multinational Corporations, Chicago, 153-177.

MacKie-Mason, Jeffrey K. (1990): Some Nonlinear Tax Effects on Asset Values and Investment Decisions under Uncertainty, in: Journal of Public Economics 42, 301-327.

Majd, Saman / Myers, Stewart C. (1985): Valuing the Government's Tax Claim on Risky Corporate Assets, NBER Working Paper No. 1553.

Majd, Saman / Myers, Stewart C. (1987): Tax Asymmetries and Corporate Income Tax Reform, in: Feldstein, Martin (ed.): The Effects of Taxation on Capital Accumulation, Chicago, 343373.

Mühlehner, Johann / Zöchling, Hans (eds.) (2004): SWK-Sonderheft - Die neue Gruppenbesteuerung, Wien.

Niemann, Rainer (2004): Asymmetric Taxation and Cross-Border Investment Decisions, CESifo Working Paper No. 1219.

Pummerer, Erich (2004): Die österreichische Gruppenbesteuerung unter Unsicherheit, Working Paper, University of Innsbruck, http://www.pummerer.at/do-wn/grbest0904.pdf (Download of 28.10.2004).

Russo, Antonio (2005): Formulary Apportionment for Europe: An Analysis and a Proposal, in: Intertax 33, 2-31.

Schneider, Dieter (1988): Was verlangt eine marktwirtschaftliche Steuerreform: Einschränkung des Verlust-Mantelkaufs oder Ausweitung des Verlustausgleichs durch handelbare Verlustverrechnungsgutscheine?, in: Betriebs-Berater 43, 1222-1229.

Scholes, Myron S. / Wolfson, Mark A. / Erickson, Merle E. / Maydew, Edward L. / Shevlin, Terry J. (2005): Taxes and Business Strategy - A Planning Approach, 3rd ed., Upper Saddle River.

Treisch, Corinna (2004): Europataugliche Ausgestaltung der Unternehmensbesteuerung, Wiesbaden. 


\section{CESifo Working Paper Series}

(for full list see www.cesifo-group.de)

1441 John Whalley, Globalization and Values, April 2005

1442 Denise L. Mauzerall, Babar Sultan, Namsoug Kim and David F. Bradford, Charging $\mathrm{NO}_{x}$ Emitters for Health Damages: An Exploratory Analysis, April 2005

1443 Britta Hamburg, Mathias Hoffmann and Joachim Keller, Consumption, Wealth and Business Cycles in Germany, April 2005

1444 Kohei Daido and Hideshi Itoh, The Pygmalion Effect: An Agency Model with Reference Dependent Preferences, April 2005

1445 John Whalley, Rationality, Irrationality and Economic Cognition, April 2005

1446 Henning Bohn, The Sustainability of Fiscal Policy in the United States, April 2005

1447 Torben M. Andersen, Is there a Role for an Active Fiscal Stabilization Policy? April 2005

1448 Hans Gersbach and Hans Haller, Bargaining Power and Equilibrium Consumption, April 2005

1449 Jerome L. Stein, The Transition Economies: A NATREX Evaluation of Research, April 2005

1450 Raymond Riezman, John Whalley and Shunming Zhang, Metrics Capturing the Degree to which Individual Economies are Globalized, April 2005

1451 Romain Ranciere, Aaron Tornell and Frank Westermann, Systemic Crises and Growth, April 2005

1452 Plutarchos Sakellaris and Focco W. Vijselaar, Capital Quality Improvement and the Sources of Growth in the Euro Area, April 2005

1453 Kevin Milligan and Michael Smart, Regional Grants as Pork Barrel Politics, April 2005

1454 Panu Poutvaara and Andreas Wagener, To Draft or not to Draft? Efficiency, Generational Incidence, and Political Economy of Military Conscription, April 2005

1455 Maurice Kugler and Hillel Rapoport, Skilled Emigration, Business Networks and Foreign Direct Investment, April 2005

1456 Yin-Wong Cheung and Eiji Fujii, Cross-Country Relative Price Volatility: Effects of Market Structure, April 2005 
1457 Margarita Katsimi and Thomas Moutos, Inequality and Relative Reliance on Tariffs: Theory and Evidence, April 2005

1458 Monika Bütler, Olivia Huguenin and Federica Teppa, Why Forcing People to Save for Retirement may Backfire, April 2005

1459 Jos Jansen, The Effects of Disclosure Regulation of an Innovative Firm, April 2005

1460 Helge Bennmarker, Kenneth Carling and Bertil Holmlund, Do Benefit Hikes Damage Job Finding? Evidence from Swedish Unemployment Insurance Reforms, May 2005

1461 Steffen Huck, Kai A. Konrad and Wieland Müller, Merger without Cost Advantages, May 2005

1462 Louis Eeckhoudt and Harris Schlesinger, Putting Risk in its Proper Place, May 2005

1463 Hui Huang, John Whalley and Shunming Zhang, Trade Liberalization in a Joint Spatial Inter-Temporal Trade Model, May 2005

1464 Mikael Priks, Optimal Rent Extraction in Pre-Industrial England and France - Default Risk and Monitoring Costs, May 2005

1465 François Ortalo-Magné and Sven Rady, Heterogeneity within Communities: A Stochastic Model with Tenure Choice, May 2005

1466 Jukka Pirttilä and Sanna Tenhunen, Pawns and Queens Revisited: Public Provision of Private Goods when Individuals make Mistakes, May 2005

1467 Ernst Fehr, Susanne Kremhelmer and Klaus M. Schmidt, Fairness and the Optimal Allocation of Ownership Rights, May 2005

1468 Bruno S. Frey, Knight Fever - Towards an Economics of Awards, May 2005

1469 Torberg Falch and Marte Rønning, The Influence of Student Achievement on Teacher Turnover, May 2005

1470 John Komlos and Peter Salamon, The Poverty of Growth with Interdependent Utility Functions, May 2005

1471 Hui Huang, Yi Wang, Yiming Wang, John Whalley and Shunming Zhang, A Trade Model with an Optimal Exchange Rate Motivated by Current Discussion of a Chinese Renminbi Float, May 2005

1472 Helge Holden, Lars Holden and Steinar Holden, Contract Adjustment under Uncertainty, May 2005

1473 Kai A. Konrad, Silent Interests and All-Pay Auctions, May 2005

1474 Ingo Vogelsang, Electricity Transmission Pricing and Performance-Based Regulation, May 2005 
1475 Spiros Bougheas and Raymond Riezman, Trade and the Distribution of Human Capital, June 2005

1476 Vesa Kanniainen, Seppo Kari and Jouko Ylä-Liedenpohja, The Start-Up and Growth Stages in Enterprise Formation: The "New View" of Dividend Taxation Reconsidered, June 2005

1477 M. Hashem Pesaran, L. Vanessa Smith and Ron P. Smith, What if the UK had Joined the Euro in 1999? An Empirical Evaluation Using a Global VAR, June 2005

1478 Chang Woon Nam and Doina Maria Radulescu, Effects of Corporate Tax Reforms on SMEs' Investment Decisions under the Particular Consideration of Inflation, June 2005

1479 Panos Hatzipanayotou, Sajal Lahiri and Michael S. Michael, Globalization, CrossBorder Pollution and Welfare, June 2005

1480 John Whalley, Pitfalls in the Use of Ad valorem Equivalent Representations of the Trade Impacts of Domestic Policies, June 2005

1481 Edward B. Barbier and Michael Rauscher, Trade and Development in a Labor Surplus Economy, June 2005

1482 Harrie A. A. Verbon and Cees A. Withagen, Tradable Emission Permits in a Federal System, June 2005

1483 Hendrik Hakenes and Andreas Irmen, On the Long-Run Evolution of Technological Knowledge, June 2005

1484 Nicolas Schmitt and Antoine Soubeyran, A Simple Model of Brain Circulation, June 2005

1485 Carsten Hefeker, Uncertainty, Wage Setting and Decision Making in a Monetary Union, June 2005

1486 Ondřej Schneider and Jan Zápal, Fiscal Policy in New EU Member States - Go East, Prudent Man!, June 2005

1487 Christian Schultz, Virtual Capacity and Competition, June 2005

1488 Yvan Lengwiler and Elmar Wolfstetter, Bid Rigging - An Analysis of Corruption in Auctions, June 2005

1489 Johannes Becker and Clemens Fuest, Does Germany Collect Revenue from Taxing Capital Income?, June 2005

1490 Axel Dreher and Panu Poutvaara, Student Flows and Migration: An Empirical Analysis, June 2005

1491 Bernd Huber and Marco Runkel, Interregional Redistribution and Budget Institutions under Asymmetric Information, June 2005 
1492 Guido Tabellini, Culture and Institutions: Economic Development in the Regions of Europe, July 2005

1493 Kurt R. Brekke and Michael Kuhn, Direct to Consumer Advertising in Pharmaceutical Markets, July 2005

1494 Martín Gonzalez-Eiras and Dirk Niepelt, Sustaining Social Security, July 2005

1495 Alfons J. Weichenrieder, (Why) Do we need Corporate Taxation?, July 2005

1496 Paolo M. Panteghini, S-Based Taxation under Default Risk, July 2005

1497 Panos Hatzipanayotou and Michael S. Michael, Migration, Tied Foreign Aid and the Welfare State, July 2005

1498 Agata Antkiewicz and John Whalley, BRICSAM and the Non-WTO, July 2005

1499 Petr Hedbávný, Ondřej Schneider and Jan Zápal, A Fiscal Rule that has Teeth: A Suggestion for a 'Fiscal Sustainability Council' underpinned by the Financial Markets, July 2005

1500 J. Atsu Amegashie and Marco Runkel, Sabotaging Potential Rivals, July 2005

1501 Heikki Oksanen, Actuarial Neutrality across Generations Applied to Public Pensions under Population Ageing: Effects on Government Finances and National Saving, July 2005

1502 Xenia Matschke, Costly Revenue-Raising and the Case for Favoring Import-Competing Industries, July 2005

1503 Horst Raff and Nicolas Schmitt, Why Parallel Trade may Raise Producers Profits, July 2005

1504 Alberto Bisin and Piero Gottardi, Efficient Competitive Equilibria with Adverse Selection, July 2005

1505 Peter A. Zadrozny, Necessary and Sufficient Restrictions for Existence of a Unique Fourth Moment of a Univariate GARCH(p,q) Process, July 2005

1506 Rainer Niemann and Corinna Treisch, Group Taxation, Asymmetric Taxation and Cross-Border Investment Incentives in Austria, July 2005 